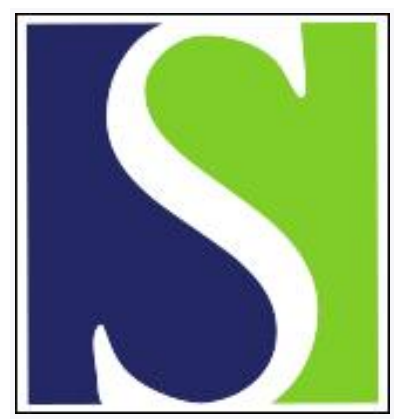

Scand J Work Environ Health 2022;48(1):1-3

https://doi.org/10.5271/sjweh.4002

Published online: 25 Nov 2021, Issue date: 01 Jan 2022

An occupational exposure limit for welding fumes is urgently needed

by Sjögren B, Albin M, Broberg K, Gustavsson P, Tinnerberg H, Johanson $\mathrm{G}$

Several countries have occupational exposure limits for welding fumes of $5 \mathrm{mg} / \mathrm{m} 3$. Given the accumulating evidence on serious health effects from welding fumes below this level, adequate worker protection including a more stringent health based occupational exposure limit is an urgent issue.

Affiliation: Integrative Toxicology, Institute of Environmental Medicine, Karolinska Institutet, Stockholm, Sweden. bengt.sjogren@ki.se

Refers to the following texts of the Journal: 1999;25(5):430-435 2002;28(1):49-57 2021;47(1):52-61

The following article refers to this text: 2022;48(6):479-489

Key terms: cancer; editorial; fume; occupational exposure; occupational exposure limit; OEL; welder; welding

This article in PubMed: www.ncbi.nlm.nih.gov/pubmed/34821369 


\section{An occupational exposure limit for welding fumes is urgently needed}

Approximately 11 million people work as welders worldwide and an additional 110 million are exposed to welding fumes at work (1). Several countries have an occupational exposure limit (OEL) for welding fumes of $5 \mathrm{mg} / \mathrm{m}^{3}(1,2)$ and similar OEL for respirable dust (2). Given the accumulating evidence on serious health effects from welding fumes $<5 \mathrm{mg} / \mathrm{m}^{3}$, adequate worker protection including a more stringent health based OEL is an urgent issue. We therefore welcome that the European Commission has assigned the European Chemical Agency (ECHA) to propose an OEL for welding fumes at the EU level, pursuant to the Carcinogens and Mutagens Directive (CAD). It should be noted that welding fumes - besides having a very complex and variable composition - are process generated and do not fall under the Registration, Evaluation, Authorisation and Restriction of Chemicals (REACH) regulation. In the following, we present some of the key issues when setting an OEL for welding fumes.

\section{Brief summary of health effects}

The International Agency for Research on Cancer has classifed welding fumes as carcinogenic to humans (1). The evaluation supports chronic inflammation and immunosuppression rather than genotoxicity as a mechanism for welding-induced lung cancer. Meta-analyses have showed increased risks for lung cancer already after 3-20 years of exposure $(3,4)$.

Several epidemiological studies have shown increased risks for ischemic heart disease among welders (5), and a meta-analysis demonstrated increased risks of ischemic heart disease [risk ratio (RR) 1.09, 95\% confidence interval (CI) 1.00-1.19, based on ten populations] as well as acute myocardial infarction (RR 1.69, 95\% Cl 1.18-2.42, based on three populations) (6). Ibfelt et al's study (7) showed an increased risk at $10-50 \mathrm{mg} / \mathrm{m}^{3}$-years (the lowest exposure category, levels are given as respirable fraction unless otherwise stated). This corresponds to $0.25-1.25 \mathrm{mg} / \mathrm{m}^{3}$ during 40 years of welding (5). Welders with a median respirable dust exposure $<1 \mathrm{mg} / \mathrm{m}^{3}(5-95$ percentile ranges 0.2-4.2 and 0.1-1.9 at two time points) developed increased systolic and diastolic blood pressure (8).

Two recent studies provide data on chronic obstructive pulmonary disease (COPD) in relation to welding fumes. A significantly increased prevalence of COPD was seen among Korean welders in both the median and high exposure tertile. The exposure in the median tertile was $3.4-11.7 \mathrm{mg} / \mathrm{m}^{3}$-years, corresponding to $0.1-0.3$ $\mathrm{mg} / \mathrm{m}^{3}$ during 40 years (9). In a population-based cohort in Sweden, exposure to welding fumes was associated with an increased incidence of COPD at a mean exposure to inhalable dust of $0.8 \mathrm{mg} / \mathrm{m}^{3}$ but not at a mean exposure of $0.08 \mathrm{mg} / \mathrm{m}^{3}(10)$.

Mild steel contains small amounts of manganese [typically <1.6\%, (1)], a known neurotoxicant (11). Gliga et al (12) found a strong correlation between respirable manganese and respirable dust during mild steel welding. According to their calculations, the current EU OEL for respirable manganese of $0.05 \mathrm{mg} / \mathrm{m}^{3}$ corresponds to 0.8 $\mathrm{mg} / \mathrm{m}^{3}$ welding fumes.

Welding fume exposure has been associated with asthma $(13,14)$, with stainless steel welding fumes as a specific risk factor. In Finland, the estimated incidence of occupational asthma among stainless steel welders was 1-2 among 1000 welders/year (15). Several epidemiological studies have shown an increased frequency of pneumonia among welders. Welding fumes have also been associated with invasive pneumococcal disease (16). Exposure estimates associated with asthma and pneumonia are lacking.

Regarding effects on reproduction, a cohort following all single births in Sweden 1994-2012 showed that pregnant women with exposure to welding fumes $\left(0.1-3.2 \mathrm{mg} / \mathrm{m}^{3}\right)$ was associated with increased risks of pre-term birth and giving birth to children with low birth weight (17). 


\section{Conclusion}

As illustrated herein, data on several types of negative health effects from welding fumes at low-to-moderate exposure levels are available, and there is an urgent need for a health-based OEL for welding fumes. This OEL should be based on a critical appraisal of all health effects of welding and take the various welding methods into account. Indeed, some countries have already introduced such OEL, eg, Denmark $\left(0.5-1.7 \mathrm{mg} / \mathrm{m}^{3}\right.$ depending on welding process and material (18) and The Netherlands $\left(1 \mathrm{mg} / \mathrm{m}^{3}(2,19)\right.$.

A general OEL for welding fumes does not replace the need for specific OEL for components such as chromium, nickel, aluminium, lead and manganese, which may be present to a variable extent depending on welding technique and material. The combined use of a general OEL and specific OEL makes it easier to ensure safe levels for different types of welding. Moreover, setting an OEL is not enough. Additional measures include local exhaust ventilation and fresh-air respirators. Furthermore, the health risks mentioned above as well as the ventilation measures need to be clearly communicated, for example in safety data sheets added to packages of welding electrodes. Furthermore, welders over the age of 50 may be recommended to vaccinate against pneumococcal pneumonia (20).

\section{References}

1. International Agency for Research on Cancer (IARC). Monographs on the Evaluation of Carcinogenic Risks to Humans. Welding, molybdenum trioxide, and indium tin oxide. Lyon: IARC; 2018; IARC monographs on the evaluation of the carcinogenic risks of chemicals to humans, vol 118: pp310.

2. Institut für Arbeitsschutz der Deutschen Gesetzlichen Unfallversicherung (IFA). GESTIS International Limit Values. Available from https://limitvalue.ifa.dguv.de/WebForm_gw2.aspx. Updated May 2021.

3. Kendzia B, Behrens T, Jöckel KH, Siemiatycki J, Kromhout H, Vermeulen R et al. Welding and lung cancer in a pooled analysis of case-control studies. Am J Epidemiol. 2013;178(10):1513-1525. https://doi.org/10.1093/aje/kwt201

4. Honaryar MK, Lunn RM, Luce D, Ahrens W, 't Mannetje A, Hansen J etl al. Welding fumes and lung cancer: a meta-analysis of casecontrol and cohort studies. Occup Environ Med. 2019;76(6):422-431. https://doi.org/10.1136/oemed-2018-105447

5. Sjögren B, Bigert C, Gustavsson P. Occupational chemical exposures and cardiovascular disease. The Nordic Expert Group for Criteria Documentation of Health Risks from Chemicals. Arbete och Hälsa. 2020;153(2):428. https://gupea.ub.gu.se/handle/2077/66225.

6. Mocevic E, Kristiansen P, Bonde JP. Risk of ischemic heart disease following occupational exposure to welding fumes: a systematic review with meta-analysis. Int Arch Occup Environ Health. 2015;88(3):259-272. https://doi.org/10.1007/s00420-014-0965-2

7. Ibfelt E, Bonde JP, Hansen J. Exposure to metal welding fume particles and risk for cardiovascular disease in Denmark: a prospective cohort study. Occup Environ Med. 2010;67(11):772-777. https://doi.org/10.1136/oem.2009.051086

8. Taj T, Gliga AR, Hedmer M, Wahlberg K, Assarsson E, Lundh T et al. Effect of welding fumes on the cardiovascular system: a six-year longitudinal study. Scand J Work Environ Health. 2021;47(1):52-61. https://doi.org/10.5271/sjweh.3908

9. Koh D-H, Kim J-I, Kim K-H, Yoo S-W, Korea Welders Cohort Group. Welding Fume Exposure and Chronic Obstructive Pulmonary Disease in Welders. Occup Med. 2015;65:72-77. https://doi.org/10.1093/occmed/kqu136

10. Grahn K, Gustavsson P, Andersson T, Lindén A, Hemmingsson T, Selander J, Wiebert P. Occupational exposure to particles and increased risk of developing chronic obstructive pulmonary disease (COPD): A population-based cohort study in Stockholm, Sweden. Environ Res. 2021;200:111739. https://doi.org/10.1016/j.envres.2021.111739

11. Park RM. Neurobehavioral deficits and parkinsonism in occupations with manganese exposure: a review of methodological issues in the epidemiological literature. Saf Health Work. 2013;4(3):123-135. https://doi.org/10.1016/j.shaw.2013.07.003

12. Gliga AR, Taj T, Wahlberg K, Lundh T, Assarsson E, Hedmer M et al. Exposure to Mild Steel Welding and Changes in Serum Proteins With Putative Neurological Function-A Longitudinal Study. Front Public Health. 2020;8:422. https://oi.org/10.3389/ fpubh.2020.00422

13. Karjalainen A, Kurppa K, Martikainen R, Karjalainen J, Klaukka T. Exploration of asthma risk by occupation--extended analysis of an incidence study of the Finnish population. Scand J Work Environ Health. 2002;28(1):49-57. https://doi.org/10.5271/sjweh.646

14. Torén K, Järvholm B, Brisman J, Hagberg S, Hermansson BA, Lillienberg L. Adult-onset asthma and occupational exposures. Scand J Work Environ Health. 1999;25(5):430-435. https://doi.org/10.5271/sjweh.456

15. Hannu T, Piipari R, Tuppurainen M, Nordman H, Tuomi T. Occupational asthma caused by stainless steel welding fumes: a clinical study. Eur Respir J. 2007;29(1):85-90. https://doi.org/10.1183/09031936.00058106 
16. Torén K, Blanc PD, Naidoo RN, Murgia N, Qvarfordt I, Aspevall O et al. Occupational exposure to dust and to fumes, work as a welder and invasive pneumococcal disease risk. Occup Environ Med. 2020;77(2):57-63. https://doi.org/10.1136/oemed-2019-106175

17. Norlén F, Gustavsson P, Wiebert P, Rylander L, Albin M, Westgren M et al. Occupational exposure to inorganic particles during pregnancy and birth outcomes: a nationwide cohort study in Sweden. BMJ Open. 2019 Feb 27;9(2):e023879. doi: 10.1136/bmjopen-2018-023879. https://doi.org/10.1136/bmjopen-2018-023879

18. Arbejdstilsynet. Bekendtgørelse om grænseværdier for stoffer og materialer. [Statutory order on Occupational exposure limits.] BEK nr 1426 af 28/06/2021. Copenhagen, Denmark: Arbejdstilsynet. 2021. https://www.retsinformation.dk/eli/lta/2021/1426.

19. Dutch Expert Committee on Occupational Standards (DECOS). Health-based recommended occupational exposure limit for ARC welding fume particles not containing chromium and nickel. Den Haag, The Netherlands: DECOS. 1993.

20. Sjögren B, Johanson G. Original title in Swedish: Svetsare kan behöva pneumokockvaccin. Nationella vaccinationsprogrammet bör omfatta denna högriskgrupp. [Welders may need pneumococcal vaccine. National immunization program should include this high-risk group]. Läkartidningen. 2014;111:454.

Bengt Sjögren (corresponding author) MD, PhD

Integrative Toxicology,

Institute of Environmental Medicine,

Karolinska Institutet,

Stockholm, Sweden

[Email: bengt.sjogren@ki.se]

Karin Broberg, PhD

Institute of Environmental Medicine,

Karolinska Institutet and

Division of Occupational and Environmental Medicine,

Lund University

Lund, Sweden

[Email: karin.broberg@ki.se]

Håkan Tinnerberg, $\mathrm{PhD}$

Institute of Medicine,

Sahlgrenska Academy,

School of Public Health,

University of Gothenburg, and

Community Medicine,

Gothenburg, Sweden

[Email: hakan.tinnerberg@amm.gu.se]
Maria Albin, MD, PhD

Unit of Occupational Medicine,

Institute of Environmental Medicine,

Karolinska Institutet,

Stockholm, Sweden

[Email: maria.albin@ki.se]

Per Gustavsson, MD, PhD

Institute of Environmental Medicine,

Karolinska Institutet and

Centre for Occupational and Environmental Medicine

Stockholm, Sweden

[Email: per.gustavsson@ki.se]

Gunnar Johanson, PhD

Integrative Toxicology,

Institute of Environmental Medicine,

Karolinska Institutet,

Stockholm, Sweden

[Email: gunnar.johanson@ki.se]

All authors contributed equally to this Editorial. 